\title{
Socio-Economic Status of Dairy Based Women Self Help Group Members under SGSY in Rewari District of Haryana, India
}

\author{
Rekha Yadav ${ }^{*}$, M. P. Sagar², Parveen Kumar ${ }^{3}$, Jyoti Yadav, \\ Deepa Singh ${ }^{1}$ and Amit Kumar ${ }^{1}$ \\ ${ }^{1}$ Division of Extension Education, IVRI, Izatnagar (UP), India \\ ${ }^{2}$ CARI, Izatnagar (UP), India \\ ${ }^{3}$ Department of Veterinary Microbiology, LUVAS, Hisar, Haryana, India \\ *Corresponding author
}

\begin{abstract}
A B S T R A C T
Keywords

SGSY, SHG, Socioeconomic status

Article Info

Accepted:

30 October 2017

Available Online:

10 November 2017

The present study was conducted in Rewari and Khol block of Rewari district Haryana, with the objective to know the socio-economic status of SHG members. The data on socioeconomic variables were collected from 90 respondents drawn from 30 SHGs. The study revealed that almost all the members were land less and found to belong to middle age group (35-46 years), married, practicing dairy as major occupation, small herd size and belonging to low income group. Hence, it may be concluded that SHG members are resource poor women farmers who have taken dairy as income generating activity for livelihood security by making access to credit through SHGs
\end{abstract}

\section{Introduction}

In India, women are responsible for growth in livestock sector. Rural women, besides performing household work, have been traditionally and predominantly engaged in agriculture, animal husbandry and dairy activities. In rural India, cattle and buffalo rearing has been traditionally been a responsibility of farm women but, women are more likely to be credit constrained, have restricted access to wage labour market and have limited decision-making and bargaining power within the household. Economic independence is essential for women's empowerment. SHGs have emerged in order to help poor women to secure inputs like credit and other services (Chandrashekar, 2009). They work for group solidarity, selfgroup awareness and social and economic empowerment through democratic functioning. The SGSY is being implemented by the District Rural Development Agencies (DRDAs) with basic objective to bring the poor families (Swarozgaris) above the poverty line (APL) by providing them incomegenerating assets through a mix of bank credit and governmental subsidy through SHG 
approach (Kasthuri, et al., 2014; Kumar and Tochhawng, 2014). It covers all aspects of self-employment of the rural poor viz. organisation of the poor in to Self Help Groups (SHGs) and their capacity building, training, selection of key activities, planning of activity clusters, infrastructure build up, technology and marketing support.

\section{Materials and Methods}

The study was conducted in purposively selected Rewari district of Haryana. The SHGs made under SGSY by DRDA, functioning for last three or more than three years, were taken in to consideration for study. Two blocks were selected purposively on the basis of maximum number of dairy based women SHGs. Further, two lists of SHGs were prepared from each block. From each list, 15 SHGs were selected. In order to select respondents, were 1office bearer and 2 other members were selected, randomly from each SHG. Thus 45 respondents were selected from each block. Therefore, the total sample size of SHG member was 90. Data were collected through personal interview schedule and analysed using suitable statistical tools.

\section{Results and Discussion}

\section{Socio- economic characteristics of the respondents}

The socio- economic characteristics of SHG members include age, caste category, education, religion, occupation, marital status, family type, family size, family education status, land holding, herd size and gross annual income.

\section{Age}

The data given in table 1 reveals that majority of respondents $(53.33 \%)$ were in middle age group followed by young $(27.78 \%)$ and old age categories $(18.89 \%)$. Table further reveals that average age under young, middle and old categories were 29.48, 39.06 and 51.58 years.

\section{Caste}

Table 2 reveals that majority of respondents $(75.56 \%)$ were belonged to SC category followed by $\mathrm{OBC}(21.11 \%)$ and General (3.33 \%). This may be due to reason that SHGs were formed by people below poverty line (BPL) and large proportion of SC and OBC lies under BPL category in the study area.

\section{Religion}

Table 3 reveals that an overwhelming majority of respondents $(98.89 \%)$ were found to belong to Hindu religion and the rest 1.11 $\%$ were muslim.

\section{Education}

Table 4 reveals that more than fifty percent respondents $(56.67 \%)$ were literate and the rest 43.33 per cent were illiterate. Amongst literates, 18.89 percent were having education up to primary level, followed by middle (14.45\%), secondary (12.22\%), functionally literate $(6.67 \%)$, higher secondary $(2.22 \%)$, graduate and post graduate $(1.11 \%$ each). The finding was supported by Kasthuri et al., (2014) and Kumar et al., (2014).

\section{Occupation}

Table 5 indicates that an overwhelming majority of respondents $(94.44 \%)$ were practicing dairy as major occupation, followed by Agriculture (5.56\%). Table further reveals that maximum respondents $(54.45 \%)$ were not engaged in any subsidiary occupation and the rest 45.55 per cent respondents were having subsidiary occupation viz., agricultural labourers(22.23 $\%)$, others $(17.77 \%)$ and dairy $(5.55 \%)$. 
Table.1 Distribution of respondents according to their age

\begin{tabular}{|l|c|c|c|}
\hline Age $($ In years) & Frequency & Percent & Average age (In years) \\
\hline Young $(23-35$ yrs $)$ & 25 & 27.78 & 29.48 \\
\hline Middle $(35-46$ yrs $)$ & 48 & 53.33 & 39.06 \\
\hline Old $(>46$ yrs) & 17 & 18.89 & 51.58 \\
\hline Overall (Mean \pm S.E) & 90 & 100 & $38.76 \pm 0.86$ \\
\hline
\end{tabular}

Table.2 Distribution of respondents according to their caste category

\begin{tabular}{|l|c|c|}
\hline Caste & Frequency & Percent \\
\hline SC & 68 & 75.56 \\
\hline OBC & 19 & 21.11 \\
\hline General & 3 & 3.33 \\
\hline
\end{tabular}

Table.3 Distribution of respondents according to their religion

\begin{tabular}{|l|c|c|}
\hline Religion & Frequency & Percent \\
\hline Hindu & 89 & 98.89 \\
\hline Muslim & 1 & 1.11 \\
\hline
\end{tabular}

Table.4 Distribution of respondents according to their education

\begin{tabular}{|l|c|c|}
\hline Education & Frequency & Percent \\
\hline Illiterate & 39 & 43.33 \\
\hline Functionally literate & 6 & 6.67 \\
\hline Primary & 17 & 18.89 \\
\hline Middle & 13 & 14.45 \\
\hline Secondary & 11 & 12.22 \\
\hline higher secondary & 2 & 2.22 \\
\hline Graduate & 1 & 1.11 \\
\hline Post graduate & 1 & 1.11 \\
\hline
\end{tabular}

Table.5 Distribution of respondents according to their occupation

\begin{tabular}{|l|c|c|c|c|}
\hline \multirow{2}{*}{ Occupation } & \multicolumn{2}{|c|}{ Major } & \multicolumn{2}{c|}{ Subsidiary } \\
\cline { 2 - 5 } & Frequency & Percent & Frequency & Percent \\
\hline House wife & 0 & 0 & 49 & 54.45 \\
\hline Dairy & 85 & 94.44 & 5 & 5.55 \\
\hline $\begin{array}{l}\text { Agriculture } \\
\text { labourer }\end{array}$ & 0 & 0 & 20 & 22.23 \\
\hline Other & 0 & 0 & 16 & 17.77 \\
\hline Agriculture & 5 & 5.56 & 0 & 0 \\
\hline
\end{tabular}


Table.6 Distribution of respondents according to their marital status

\begin{tabular}{|l|l|l|}
\hline Marital status & Frequency & Percent \\
\hline Married & 80 & 88.89 \\
\hline Unmarried & 1 & 1.11 \\
\hline Widow & 9 & 10.00 \\
\hline
\end{tabular}

Table.7 Distribution of respondents according to their family type

\begin{tabular}{|l|l|l|}
\hline Family type & Frequency & Percent \\
\hline Nuclear & 85 & 94.44 \\
\hline Joint & 5 & 5.56 \\
\hline
\end{tabular}

Table.8 Distribution of respondents according to their family size

\begin{tabular}{|l|l|l|l|}
\hline Family size & Frequency & Percent & Average family size \\
\hline Small (up to 5) & 60 & 66.67 & 4.3 \\
\hline Medium (6-9) & 27 & 30.00 & 6.7 \\
\hline Large (>9) & 3 & 3.33 & 10.6 \\
\hline Overall (Mean \pm S.E) & 90 & 100 & $5.27 \pm 0.17$ \\
\hline
\end{tabular}

Table.9 Distribution of respondents according to their family education status

\begin{tabular}{|l|l|l|l|}
\hline Family education status & Frequency & Percent & $\begin{array}{l}\text { Average Family } \\
\text { education status }\end{array}$ \\
\hline Low (1-2.8) & 52 & 57.78 & 2.20 \\
\hline Medium (2.9-4.7) & 36 & 40 & 3.6 \\
\hline High (4.8-6.5) & 2 & 2.22 & 5.75 \\
\hline Overall (Mean \pm S.E) & 90 & 100 & $2.84 \pm 0.10$ \\
\hline
\end{tabular}

Table.10 Distribution of respondents according to their land holding

\begin{tabular}{|l|l|l|l|}
\hline Land holding (ha) & Frequency & Percent & $\begin{array}{l}\text { Average land holding } \\
\text { (ha) }\end{array}$ \\
\hline Landless & 84 & 93.33 & \multirow{2}{*}{$0.03 \pm 0.014$} \\
\hline Marginal (upto 1) & 6 & 6.67 & \\
\hline
\end{tabular}

Table.11 Distribution of respondents according to their herd size

\begin{tabular}{|l|l|l|l|}
\hline $\begin{array}{l}\text { Herd size } \\
\text { (cattle equivalent score) }\end{array}$ & Frequency & Percent & Average herd size \\
\hline Small (1.26-2.95) & 78 & 86.67 & $2.33 \pm 0.096$ \\
\hline Medium (2.95-4.64) & 8 & 8.89 & \\
\cline { 1 - 3 } Large (4.64-6.33) & 4 & 4.44 & \\
\hline
\end{tabular}


Table.12 Distribution of respondents according to their Income from dairy

\begin{tabular}{|l|l|l|l|}
\hline Income level (In Rs) & Frequency & Percent & Average Income (In Rs) \\
\hline Low (15000-31683) & 54 & 60.00 & 24873.61 \\
\hline Medium (31684-48366) & 31 & 34.44 & 37875.80 \\
\hline High $(>48367)$ & 5 & 5.56 & 59540 \\
\hline overall & 90 & 100.00 & 31278.05 \\
\hline
\end{tabular}

Table.13 Distribution of respondents according to their gross annual income

\begin{tabular}{|l|l|l|l|}
\hline Gross annual income (In Rs.) & Frequency & Percent & Average Income (In Rs.) \\
\hline Low (20000-45000) & 71 & 78.88 & 31599.92 \\
\hline Medium (45001-70001) & 15 & 16.67 & 55653.33 \\
\hline High (>700001) & 4 & 4.45 & 85762.5 \\
\hline overall & 90 & 100 & 38016.05 \\
\hline
\end{tabular}

Finding was in contrast of Kumar et al., (2014) who reported that majority of respondents $(57.1 \%)$ were having agriculture as primary occupation. Reason behind the finding that only 5 per cent respondents have agriculture as primary occupation because majority of respondents were landless.

\section{Marital status}

Table 6 indicates that an overwhelming majority of respondents $(88.89 \%)$ were married followed by widow $(10 \%)$ and unmarried $(1.11 \%)$. Similar findings were reported by Chandrashekar and Lokesh (2009), and Das (2012).

\section{Family type}

Table 7 indicates that an overwhelming majority of respondents $(94.44 \%)$ were having nuclear family system and rest 5.56 percent were found to belong to joint type family. Kasthuri et al., (2014) also reported similar finding and reveals that majority of women self-help group members (93.3\%) lived in nuclear family system.

\section{Family size}

Table 8 indicates that maximum respondents $(66.67 \%)$ belonged to small size family (up to 5) followed by medium (30\%, $6-9$ members) and large (3.33\%, > 9 members). Finding was supported by Kasthuri et al., (2014) who reported that more than fifty percent respondents were belonging to small family size (up to 4). Table further reveals that average size of small, medium and large family were 4.3, 6.7 and 10.6.

\section{Family education status}

Table 9 reveals that more than fifty percent respondents (57.78\%) were found to belong in low family education status category followed by medium (40\%) and high (2.22\%) family education status. Average family education status in low, medium and high category were 2.20, 3.6 and 5.75, respectively. Overall average family education status was 2.84 .

Table 10 indicates that an overwhelming majority of respondents $(93.33 \%)$ were landless followed by marginal $(6.67 \%)$ land 
holding. The average land holding was 0.03 ha.

\section{Herd size}

Table 11 indicates that majority of respondents $(86.67 \%)$ had small herd size followed by medium $(8.89 \%)$ and large (4-44 $\%)$ herd size. The average herd size was found to be 2.33 .

\section{Income from dairy}

Table 12 reveals that sixty percent of respondents were found to belong to low income level category (between Rs 15000$31683)$ followed by medium (34.44\%) and high (5.56 \%) with average Rs. 24873.61, 37875.80 , and 59540, respectively. Overall average Income was Rs. 31278.05.

\section{Gross annual income}

Table 13 reveals that more than two third majority of respondents $(78.88 \%)$ were fallen in low gross annual income category followed by medium $(16.67 \%)$ and high (4.45 \%) income level. Overall average income was Rs. 38016.05 .
In view of the above findings, it may be concluded that SHG members are resource poor women farmers who have taken dairy as income generating activity for livelihood security by making access to credit through SHGs as almost all the members were land less and found to belong to middle age group (35-46 years), married, belonging to SC and from BPL category and practicing dairy as major occupation.

\section{References}

Chandrashekar, H. M. and M. U. L. 2009. Role of SHGs in socio-economic change of vulnerable poor. International NGO Journal, 4 (4): 127131.

Kasthuri, R., Thamilarasan, Arul, S., Jayaraman, K. 2014. A case study of Self Help Group in Dharmapuri District. International Journal of Business and Administration Research Review, 2(4): 135.

Kumar, S. and Tochhawng, L. 2014. Social empowerment of women Self Help Group members engaged in livestock rearing. Indian Res. J. Ext. Edu., 14 (2).

\section{How to cite this article:}

Rekha Yadav, M. P. Sagar, Parveen Kumar, Jyoti Yadav, Deepa Singh and Amit Kumar. 2017. Socio-Economic Status of Dairy Based Women Self Help Group Members under SGSY in Rewari District of Haryana, India. Int.J.Curr.Microbiol.App.Sci. 6(11): 5385-5390. doi: https://doi.org/10.20546/ijcmas.2017.611.515 